\title{
The Impact of Private Equity on Firms' Patenting Activity
}

\author{
Kevin Amess ${ }^{*}$, Joel Stiebale ${ }^{* *}$ and Mike Wright ${ }^{* * *}$ \\ July 2015 \\ *CMBOR and Nottingham University Business School, Nottingham, UK. \\ ${ }^{* *}$ Düsseldorf Institute for Competition Economics (DICE), Düsseldorf, Germany \\ ${ }^{* * *}$ CMBOR and ERC, Imperial College, London, UK and University of Ghent
}

\begin{abstract}
The paper analyses the impact of private equity (PE) backed leveraged buyouts (LBOs) on innovative output (patenting). Using a sample of 407 UK deals we find that LBOs have a positive causal effect on patent stock and quality-adjusted patent stock. Our results imply a $6 \%$ increase in quality-adjusted patent stock three years after the deal. The increase in innovative activity is concentrated among private-to-private transactions with a $14 \%$ increase in the quality-adjusted patent stock. We also find evidence suggesting that PE firms facilitate the relaxation of financial constraints. In sum, our findings suggest that PE firms do not promote short-term cost-cutting at the expense of entrepreneurial investment opportunities with a long-term pay-off.
\end{abstract}

JEL Classification: D22, G32, G34, L26

Key words: private equity, leveraged buyout, entrepreneurial buyouts, innovation 


\section{Introduction}

Private equity (PE) firms establish funds in order to raise capital that is then put towards the acquisition of a portfolio of mature firms (Kaplan and Stromberg, 2009). The 'portfolio firms' are acquired via a Leveraged Buyout (LBO) because PE firms will use debt finance, secured against portfolio firms' assets and/or future cash flows, in order to facilitate the transaction (Gilligan and Wright, 2014). There is controversy, however, regarding the 'real' economic consequences for firms subject to an LBO (Cumming et al., 2007). Proponents argue that the LBO governance structure creates incentives for managers to generate value by reducing unprofitable discretionary expenditures and pursuing profitable growth opportunities (Jensen, 1986; Wright et al, 2000; Boucly et al., 2011). ${ }^{1}$ In contrast, critics argue that PE firms' short-term investment horizon promotes the generation of short-term profit and high leverage diverts cash away from longer-term investments towards servicing debt (Rappaport, 1990).

Whether LBOs create financial incentives to make entrepreneurial investments with a longerterm payoff or focus on short-term cost-cutting is a long-standing controversy. Empirical analysis of innovative activity is well-suited to addressing the controversy because it typically involves making investments that yield a longer-term pay-off. If LBOs create incentives to pursue profitable opportunities that have a longer-term pay-off, we expect to observe an increase in productive innovation. Some prior studies have examined R\&D expenditure (e.g. Lichtenberg and Siegel, 1990; Long and Ravenscraft, 1993); however, it is a problematic measure of innovative activity because it is unable to distinguish between productive and unproductive expenditure. Evidence suggests that LBO firms make more productive use of R\&D expenditure by improving product development and the commercialization of

\footnotetext{
${ }^{1}$ Key features of the LBO governance structure are: active PE investors with board representation, debt bonding, and strong management incentives derived from their equity ownership (Jensen, 1986; Thompson and Wright, 1995).
} 
technology (Zahra, 1995). This is because LBOs provide incentives to adopt entrepreneurial practices and innovation strategies to exploit their R\&D investments (Bruining et al., 2013; Link et al., 2014). Analysis of innovative output therefore provides better understanding of LBOs' impact on firms' longer-term prospects.

Patents are a widely used measure of innovation outcomes and are useful for the purpose of analyzing LBOs impact on innovation because they are observable in privately owned firms, unlike R\&D expenditure. Lerner et al. (2011) find that firms' level of patenting does not change post-LBO but patents are more frequently cited, which suggests that portfolio firms are producing research that has greater economic impact; however, they are unable to determine whether this is a selection or a causal effect. Ughetto (2010) shows the impact of PE firms on innovation outcomes is not necessarily uniform; PE firms' size, stage specialization, and geographical location as well as deal characteristics are correlated with portfolio firms' patent activity. A limitation of her research is that due to the absence of nonPE backed firms in the sample, she does not establish whether PE-backed LBOs lead to greater patenting activity. We identify a causal relationship between a PE-backed LBO and patent activity and seek to establish PE firms' role as a source of entrepreneurial finance that relaxes LBO targets' financial constraints. We recognize that financial constraints are notoriously difficult to measure and adopt various approaches to analyzing this impact.

The remainder of the paper is organized as follows. Section 2 summarizes the theoretical arguments in the related literature, section 3 describes the empirical strategy, and section 4 provides a description of the data. Results of the empirical analysis are presented in section 5 and section 6 concludes. 


\section{Theoretical considerations}

The paper is concerned with the effect of PE firms on financial constraints and therefore the funding of innovation. We therefore focus on the role of PE firms as a source of entrepreneurial finance in the capital market.

\subsection{PE firms can reduce external capital market imperfections}

Capital markets are fraught with information asymmetries. Suppliers of finance are confronted with an adverse selection problem leading to the rationing of finance (Stiglitz and Weiss, 1981). In such a scenario firms underinvest in a variety of activities, including $R \& D$ (Hubbard, 1998). Since asymmetric information problems are probably more pronounced for R\&D than for tangible investment, and the collateral value of intangible assets is limited, financial constraints are arguably more severe for the financing of innovation (Brown et al., 2012). Further, the riskiness of R\&D makes debt financing particularly difficult to obtain, since in contrast to equity market investors, creditors do not benefit from upside returns (Brown et al., 2009; Hsu et al., 2014). Financial development is therefore important in relaxing financial constraints, leading to more innovation (Laeven et al. 2013; Amore et al., 2013). We argue below that PE plays an important role in relaxing financial constraints and facilitating innovative activity.

The extent to which different types of firms are financially constrained and suffer from underinvestment varies (Boucly et al., 2011). Expectations regarding listed corporations are somewhat ambiguous. Listed corporations are generally expected to experience little

underinvestment due to the financing constraints that result from investor asymmetric information. However, some listed corporations may face financing constraints because short-term investors are unwilling to allow them the time and resources they need to innovate 
in order to achieve longer-term pay-offs. Going private through an LBO may relieve these financing constraints as PE investors have a longer time horizon than stock market investors (Lerner et al., 2011). The argument for going private in order to innovate also rests on the assumption that PE investors have specialist expertise that gives them both better information and the ability to act on that information than stock market investors. Moreover, although after the LBO a firm takes on debt repayment commitments, LBOs are not homogeneous regarding innovative potential, the amount of leverage involved and the amount of debt they can service. PE firms use their expertise to take account of these differences in the structuring of the deal. LBOs focused on enhancing efficiency are typically seen by PE firms as deals able to service high debt repayment commitments. In contrast, lower debt levels may be used to provide the flexibility to undertake risky innovative activities (Wright et al., 2000). In our empirical analysis below we introduce controls for the amount of leverage.

In contrast, to publicly listed corporations, private firms suffer from underinvestment due to their reliance on internal finance (Carpenter and Petersen, 2002) and difficulties in accessing finance from banks (Behr et al., 2013). This is because private firms find difficulty in conveying information to finance providers (Behr et al., 2013). Further, the goals and behavior of private firm owners may also constrain access to external finance to fund innovation. For instance, private firm owners may seek to retain control and hence be reluctant to dilute ownership through opening up their share capital to external investors.

$\mathrm{PE}$ is able to attenuate these capital market imperfections, leading to increased investment after an LBO (Berger and Udell, 1998; Engel and Stiebale, 2014). Boucly et al. (2011) identify mechanisms associated with corporate governance and financial expertise through which PE firms facilitate access to finance; hence, relaxing financial constraints. First, PE 
firms are active investors who monitor senior management performance and their strategic decisions. This is facilitated by representation on the board of directors. This improvement in corporate governance helps overcome the moral hazard problem, providing creditors with the confidence that funds are used productively. Second, PE firms' financial expertise is a reassurance to creditors, making it more likely they will provide funds for investment. Consequently, portfolio firms are less likely to suffer from underinvestment than private firms with no PE firm involvement. If private firms were underfunding innovation activity prior to an $\mathrm{LBO}$, we expect to observe an increase in innovation activity after an LBO. Correspondingly, for those LBOs that subsequently go through a second buyout (SBO), which involves a PE firm acquiring a portfolio firm from another PE firm (Alperovych et al., 2013), we expect to observe little if any increase in innovation activity after SBO. This is likely to be the case where the incoming PE firm is performing the same functions as the outgoing PE firm. In contrast, an incoming PE firm with larger funds available and greater expertise may be able to facilitate more innovation activity.

\subsection{Divisional buyouts and internal capital market imperfections}

Williamson $(1975,1985)$ argues that large organizations adopt a divisional organizational structure and use an internal capital market to allocate resources due to the failure of the external capital market in overcoming information asymmetries. A potential advantage of the internal capital market is its superior access to information compared to the external capital market. The audit function of head office and its ability to gather information enables head office to make superior capital allocation decisions than the external capital market. The divisions, being profit centers, are allocated financial resources on the basis of the return they are able to generate. Efficient decision-making involves operational decisions being taken at divisional level while strategic and capital allocation decisions are taken at corporate head 
office level. These features allow it to act as an effective hierarchical governance device with divisional managers' focusing on profit maximization (Williamson, 1985).

Williamson (1985) acknowledges that there are limits to the effectiveness of the internal capital market as a control, incentive and governance device. Such limits allow divisional managers to indulge in opportunism and 'politicking', resulting in misallocation of resources. When superficial investment decision-making is present, the firm is likely to underperform (Hill, 1988), leading to pressure for diversified firms to refocus their activities (Berger and Ofek, 1999). In addition, such firms are more likely to be subject to a takeover because the transfer of financial resources within the internal capital market accommodates the waste of free cash flow (Comment and Jarrell, 1995).

The emergence of PE represents an important development in the external capital market. It facilitates external capital market allocation that might previously have been transacted in an internal capital market. With board representation facilitating the close monitoring of senior management and their strategic decisions, PE firms are active investors in their portfolio firms. As mentioned in section 2.1, this allows PE firms to reduce the information asymmetries associated with external capital market allocation, negating the need for some firms to operate within a divisional structure. Moreover, divisions that once suffered underinvestment due to capital misallocation within the internal capital market can now operate as independent firms and receive financial resources for innovation. If a division suffers from underinvestment while operating within an internal capital market, the LBO of a division is expected to reduce underinvestment. Consequently, profitable investment opportunities are more likely to be funded after the LBO of a division, leading to an increase in innovation activity. 
This section has established two competing arguments. First, difficulties in overcoming informational asymmetries in the external capital market can lead to capital allocation and investment occurring in the internal capital market. Second, the internal capital market is a flawed system of capital allocation, leading to underinvestment, and the LBO of a division can reduce underinvestment because a PE firm is able to facilitate access to external finance. The empirical analysis addresses this issue by examining the impact of divisional buyouts on innovation activity. If PE firms reduce external capital market imperfections, making capital allocation superior to the internal capital market and reducing underinvestment, we expect to observe an increase in innovation activity after a divisional buyout.

\section{Estimation strategy}

Our empirical strategy aims to identify the causal effect of PE-backed LBOs on firms' innovation outcomes. For this purpose, we employ a propensity score matching procedure (to construct the counterfactual) and combine it with a difference-in-differences estimator in order to evaluate the impact of an LBO on portfolio firms.

The evaluation of an average treatment effect on the treated (ATT) $s$ periods after a treatment period $t$ comprises a comparison between the actual innovation outcome of a firm treated to a PE-backed LBO and the situation had the firm not been acquired. The quantity measured is expressed as

$$
A T T=E\left[I_{t+s}^{1} \mid X_{t-1,} P E_{t}=1\right]-E\left[I_{t+s}^{0} \mid X_{t-1,} P E_{t}=1\right]
$$

where $I_{t+s}^{1}$ is the innovation outcome of a portfolio firm in period $t+s, I_{t+s}^{0}$ is the innovation outcome of the portfolio firm would have experienced had it not been subject to an LBO (i.e. 
the counterfactual), $X$ contains a set of control variables, and $P E$ is a dummy variable taking the value one if the firm has been subject to an LBO in any respective year.

Causal inference relies on construction of the counterfactual for the last term in equation (1), $E\left[I_{t+s}^{0} \mid X_{t-1}, P E_{t}=0\right]$. The construction of the counterfactual is not straightforward if LBO targets are not randomly selected from the population of firms. For instance, PE firms might select LBO targets because there is scope for improvement in innovation activity. In this case, using a randomly selected control sample represents an inadequate approximation of the counterfactual, rendering measures of the ATT subject to sample selection bias. In their study, Lerner et al (2011) identify this problem as a limitation of their analysis.

While there is no straightforward solution to the sample selection problem, we attempt to mitigate it by constructing a control sample using propensity score matching, proposed by Rosenbaum and Rubin (1983). The predicted probability (propensity score) of being subject to an LBO and becoming a portfolio firm, $\operatorname{Pr}\left(P E_{t}=1 \mid X_{t-1}\right)$, is obtained from the estimation of a Probit model. The vector $X_{t-1}$ contains only pre-LBO characteristics in order to avoid reverse causality problems (Caliendo and Kopeinig, 2008). As we exploit a panel data set, we can relax the assumption of selection on observables by combining the matching technique with a difference-in-differences estimator (see, for instance, Blundell and Costa Dias, 2000). Although this assumes that any unobserved differences between firms are constant over time.

Instead of comparing differences in the innovation levels between the two groups, we focus on the growth of the innovation stock (Guadalupe et al., 2012; Seru, 2014). This procedure allows the selection into the group of PE firms to be based on the expected impact on innovation and on time invariant unobservable characteristics (Heckman, Ichimura, and Todd 
1997). Nevertheless, unobserved time-varying factors that influence both LBO probability and the innovation outcomes, as well as heterogeneous responses to macroeconomic shocks across treatment and control groups, would lead to biased estimates.

The difference-in-differences estimator, measuring the effect on innovation of a firm being subject to an $\mathrm{LBO}$, is expressed as:

$$
E\left[I_{t+s}^{1}-I_{t-1} \mid X_{t-1}, P E_{t}=1\right]-E\left[I_{t+s}^{0}-I_{t-1} \mid X_{t-1}, P E_{t}=0\right]
$$

In practice, this difference-in-differences estimator can be obtained by applying weighted least squares to the matched data set, with the change in the innovation stock as the dependent variable:

$$
\Delta I_{i, t+s}^{1}=\alpha+\theta P E_{i t}+\eta_{t}+\varepsilon_{i t}
$$

$\theta$ is the difference-in-difference estimate of the $A T T, \eta_{t}$ represents time dummies and $\varepsilon_{i t}$ is an error term. This representation makes the analysis of heterogeneous effects across characteristics of portfolio firms straight forward using the following estimation equation:

$$
\Delta I_{i, t+s}^{1}=\alpha+\theta_{0} P E_{i t}+\theta_{1} P E_{i t} Z_{i 1 t}+\ldots+\theta_{K} P E_{i t} Z_{i K t}+\eta_{t}+\varepsilon_{i t}
$$

where $Z_{i k t}, k=1, \ldots K$, are characteristics of portfolio firms or PE investors to be considered.

Different estimators are proposed in the matching literature. In this paper we primarily focus on results obtained from nearest neighbor matching without replacement, which means that each portfolio firm has one comparison firm, implying each LBO firm and each matched non-LBO firm is given a weight of one. We have also experimented with a propensity score reweighting estimator (e.g. Imbens, 2004) where we assign a weight equal to $\hat{\operatorname{Pr}}\left(P E_{t}=1 \mid X_{t-1}\right) /\left(1-\hat{\operatorname{Pr}}\left(P E_{t}=1 \mid X_{t-1}\right)\right)$ for all non-LBO firms. 


\section{Data and variables}

\subsection{Data sets}

The data set employed is constructed from three sources: the Center for Management Buyout Research (CMBOR), FAME, and PATSTAT. Data on PE firms and portfolio firms comes from the CMBOR, which provides information on LBO deals. The CMBOR database is compiled from a wide range of sources, including biannual surveys of financiers, press releases, stock exchange circulars, and specialist finance and press coverage. The database has no lower size cut-off, enabling the examination of the full size range and vendor type of buyouts; this is especially important for the incorporation of LBOs that were previously under private ownership (private-to-private transactions).

The second data source is the FAME database, which provides financial and accounting data for UK firms. ${ }^{2}$ The FAME database provides information on firms' sales, productivity, profitability, capital, wages and industry affiliation. Unconsolidated accounts are chosen to separate economic activity in portfolio firms from parent companies.

The third data source is PATSTAT, developed by the European Patent Office (EPO) and the OECD, which provides data on patent applications and citations. We extract patent applications for the years 1978-2008 for all firms in our sample. The data on patent applications are merged with the other firm-level data sets using a computer supported search algorithm based on the firms' names, addresses and zip (postal) codes. Every match was checked manually to ensure a good match. We only consider patents that are ultimately granted but date them back to the application year. This is to ensure that our results measure

\footnotetext{
${ }^{2}$ The database contains the subset of UK firms from the Amadeus database which has been used in numerous empirical studies (see, for instance, Budd et al., 2005; Helpman et al., 2004; Konings and Vandenbussche, 2005).
} 
the timing of an innovation but are not affected by the length of the patent granting process. Besides patent applications, the data allows identifying information on patent citations. We weight patent applications by forward citations to construct a quality-adjusted measure of patent counts. In addition, the time dimension allows the construction of an innovation stock for each firm, which we simply define as the cumulative number of (citation-weighted) patent applications.

Our estimation sample is based on the years 1998 to 2008. LBOs take place between 1998 and 2005 as we restrict the analysis to firm-year observations for which information on patenting and citations are available for at least three prospective years after a buyout (we relax this restriction in robustness checks described in section 5.4). The analysis is based on 143,653 firm-year observations in total. The estimation sample includes 35,081 firms and 407 buyouts. 1,689 non-PE backed and 239 buyout firms file at least one patent application during the sample period.

\subsection{Variables}

Our main outcome variables are based on patent applications and the patent applications weighted by forward citations, i.e. changes in innovation stocks over time. These variables have previously been employed as measures of innovation activity (e.g. Lerner et al., 2011; Seru, 2014). The empirical analysis determines and quantifies the causal relationship between LBOs and the patent variables.

Using patents as an innovation indicator has both advantages and disadvantages over alternative measures (see e.g. Griliches, 1998). In contrast to R\&D expenditures, patents are (at least an intermediate) innovation output indicator and thus also account for the 
effectiveness with which innovation is pursued. Further, as the number of patents is derived from administrative data, this indicator does not have to rely on self-reported measures of new products and processes, which are often used in innovation studies. Patenting is costly and a granted patent requires a certain degree of novelty which reduces the risk of counting innovations of little relevance. Finally, the number of patents is a well-established indicator of innovation which has been used in several recent studies ${ }^{3}$ and patent applications seem to be highly correlated with other common indicators of innovative performance (e.g. Hagedoorn and Cloodt, 2003; Griliches, 1998).

The downside of taking patents as an innovation indicator is that not every invention becomes patented, and - depending on firms' innovation strategies - firms may make more or less use of formal IP rights protection (e.g. Hall and Ziedonis, 2001; Ziedonis, 2004). It can also be expected that there will be substantial variation in the value of patented innovations. To partly address this problem, the results for patent counts are compared with those using citation-weighted patents, which are likely to be correlated with the importance of innovations. If $\mathrm{PE}$ firms induce an increase (decrease) in patenting for purely strategic reasons, we should see an increase (decrease) in the number of non-weighted patents but little change in citation-weighted patents (e.g. Bloom et al., 2011).

The choice of conditioning variables included in the Probit model that generates the propensity score used to select firms into the comparison group is based on recent innovation studies (e.g. Guadalupe et al., 2012). In particular, we construct our comparison group based on pre-buyout characteristics such as firm size (the log of sales, ln_sales), labour productivity (the log of sales per employee, In_Labprod), exporting (an exporter dummy, d_export), skill

\footnotetext{
${ }^{3}$ See, for instance, Aghion et al. (2013), Bena and Li (2014) and Seru (2014).
} 
intensity (the log of the average wage, In_av_wage), debt (liabilities divided by equity, leverage), profitability (profit divided by sales, profit_sales) and age (log firm age, In_age). We also control for pre-buyout values of our outcome variables (patent stock and patent citation stock) to ensure that our results are not affected by PE investors choosing firms based on previous innovation outcomes. Finally, the Probit model includes two-digit industry dummies and time dummies. Table 1 contains summary statistics and variable definitions. ${ }^{4}$

\section{Results}

\subsection{Propensity score matching}

The results from the Probit regression, used to generate propensity scores, are reported in Table 2. In this model, we regress an indicator of LBOs in time period $t$ on control variables in $t-1$. We restrict the analysis to firms for which information on patents in time periods $t+1$, $t+2$ and $t+3$ are available. The results show that PE firms tend to acquire relatively large but unproductive firms. Firm age as well as exporting reduces the likelihood of a buyout. In contrast, profitability, average wages, capital intensity, and previous innovation activity do not have a statistically significant impact on a firm being targeted for an LBO.

While the Probit regression results are interesting in their own right, the principal purpose of the Probit regression is to generate a propensity score that is used to match firms in the LBO sample with firms that have not been subject to an LBO. The propensity score matching method is a reliable and robust method for determining and quantifying the effect of LBOs on innovation outcomes if the potential innovation outcomes of the LBO sample and the comparison group are independent of the incidence of LBOs (conditional independence assumption). Under the 'balancing condition', the firm-specific variables included in the

\footnotetext{
${ }^{4}$ Because of space limitations we do not provide a detailed breakdown of the industrial distribution. This is available from the authors on request.
} 
Probit model should be balanced between the portfolio firms and the comparison group. This is crucial because it ensures that the propensity score obtained from the Probit regression is successful in controlling for firm-specific differences between LBO targets and the comparison group in the pre-LBO period. We test the balancing property by conducting ttests on each variable included in the Probit model to test for equality of means between LBO targets and the comparison group. The tests are reported in Table 3. While t-tests indicate statistically significant differences between the means of the LBO targets and the unmatched control sample for some variables - and most importantly the propensity score - we cannot reject equality of mean values for all control variables in the matched sample at conventional levels of significance (this is also individually and jointly true for industry and time dummies which are not shown in the table). This suggests that propensity score matching has been successful in controlling for observed firm-specific differences between LBO targets and the comparison group of firms. ${ }^{5}$

\subsection{Estimates from differences-in-differences combined with propensity score matching}

Having established that the LBO firms and the comparison group are adequately matched, we report difference-in-difference estimates based on the matched sample. Table 4 presents results showing the effects of a PE-backed LBO on the number of patents and the number of citation-weighted patents. We show the effects for up to three years after an LBO, where $t$ is the year of the transaction. Panel A shows that the ATT of an LBO on non-weighted patents. By year $t+3$, the patent stock increases by about one-third of a patent. The average effect of an LBO on quality-adjusted patents is also positive. Panel B shows that by year $t+3$ the quality-adjusted patent stock increases by about 1.3. Table 1 shows that the average number of citation-weighted patent applications each year is about one; the cumulated 1.3 increase

\footnotetext{
${ }^{5} \mathrm{We}$ also found that the distributions of propensity scores across LBOs and matched controls are very similar. A graph documenting these distributions is available upon request.
} 
after 3 years therefore implies that quality-adjusted patent applications after 3 years are on average about $40 \%$ higher due to an LBO. Table 1 also shows that the citation-weighted patent stock is about 20.6 and so the 1.3 increase implies an increase in the citation-weighted patent stock by more than $6 \%$ after 3 years. The results in Table 4 suggest that PE-backed LBOs are not only associated with an increase in patenting (Panel A), but quality-adjusted innovation output also increases (Panel B).

Instead of using a balanced panel of LBOs and potential controls for which three years of data on post-LBO patenting are available, we also estimate ATT using an unbalanced panel. This allows us to follow a greater number of portfolio firms over a longer time period of up to 5 years after an LBO. The results are documented in Table A3 in the appendix. Both the effects on patents and citation-weighted patents increase over time even though the sample size decreases over time. Note, however, that in periods $t+4$ and $t+5$ only the effect on citation-weighted patent stock is statistically significant and not the effect on patent stock, possibly due to the smaller number of observations, The results confirm our previous estimates and indicate that innovation outcomes steadily improve after a buyout.

Having established that the average LBO has a positive effect on innovation outcomes, we conduct further analysis on the role of PE firms in target firms' financial constraints. The possible presence of financial constraints in the target firm is not directly observable; however, the arguments presented in Section 2 suggest any post-LBO effect on innovation outcomes will depend on pre-LBO ownership type because ownership structure impacts on any financial constraints on investment in innovation. Therefore, following the approach of Boucly et al. (2011), we break our LBO sample into four deal types based on pre-LBO 
ownership: private-to-private transactions (Priv2Priv), public-to-private transactions (Pub2Priv), divisional buyouts and secondary buyouts.

The heterogeneous effects of deal types are reported in Table 5. It shows that the private-toprivate transaction is the only deal type that has a statistically significant effect on innovation outcomes. By year $t+3$ after the LBO the patent stock has increased by nearly one patent (see Panel A) and the quality-adjusted patent stock has increased by nearly three (Panel B), which implies a $14 \%$ increase in the quality-adjusted patent stock. There is limited and weak evidence (significance at the $10 \%$ level) that public-to-private transactions and divisional buyouts reduce patent activity.

Overall, these findings are consistent with PE firms alleviating financial constraints in private firms and facilitating investment in increased innovation outcomes. PE firms do not have such an impact on other pre-LBO ownership types, however. Indeed, the findings are consistent with PE investors being no more superior in funding innovation than stock market investors, the internal capital market, and primary buyouts investors. ${ }^{6}$

\subsection{Additional financial constraints analysis}

In order to provide additional support for the argument that PE firms alleviate financial constraints we conduct two further sets of analysis using a constructed financial dependence measure and an indicator of creditworthiness provided by FAME which is labelled "Quiscore" to proxy financial constraints. If the financial constraint hypothesis is true, PE

\footnotetext{
${ }^{6}$ We seek to confirm the finding for private-to-private deals by adopting a model specification that compares private-to-private deal types with all other remaining PE-backed LBO transactions. Results documented in a supplementary appendix which is available upon request confirm that the effects of private-to-private transactions on patent stock and quality-adjusted patents are significantly larger than that for other deal types.As we discuss in section 5.4, an alternative propensity matching approach based on private-to-private transactions only leads to very similar results.
} 
firms will have the largest impact on innovation in industries which are more dependent on external finance. Moreover, we expect this to be more pronounced in private-to-private deals, given our previous results. For this analysis, we construct a measure of industry-level financial dependence proposed by Rajan and Zingales, (1998). It is defined as the difference between investment and internal cash flow from operations. Previous evidence indicates that financing constraints are more binding for firms in industries with a high financial dependence. In particular, it has been shown that firms in industries that depend on external finance to a high extent benefit most from stock market and banking development (Amore et al., 2013, Rajan and Zingales, 1998). Hence, if LBOs reduce financing constraints in portfolio firms, we expect a positive interaction term between PE and financial dependence.

A financial dependence measure is constructed from Compustat data on listed US firms as in previous empirical analyses (e.g. Kroszner et al., 2007). Using data on listed firms in the US has two possible advantages. First, listed firms in the US arguably have relatively few financing obstacles, thus they allow us to measure an industry's technical dependence on external finance. Second, using a measure of US industries reduces endogeneity concerns as the UK firms in our sample are unlikely to affect investment and financing decisions of US firms. However, we also check the robustness of the results using a measure calculated from UK firms.

Results from the financial dependence analysis are reported in Table 6. The results in Panel A confirm previous findings that LBOs have a positive effect on the innovation outcomes of private-to-private transactions but not for other vendor source types (indicated by the coefficients for $P E \times$ Priv2Priv and $P E$ variables, respectively). Importantly, the positive effect of private-to-private transaction increases in innovation is notably larger in the 
presence of greater financial dependence (indicated by the coefficient of $P E \times$ Priv 2 Priv $\times$ findep). These findings are more pronounced for the quality-adjusted patent stock, reported in Panel B. It shows that private-to-private deals taking place in industries with no financial dependence have only a weak positive effect in $t+1$ and no significant effect in subsequent years. In contrast, the impact of private-to-private LBO transactions on the quality-adjusted patent stock increases considerably and statistically significantly with financial dependence. This is consistent with PE firms increasing innovation outcomes through the relaxation of financial constraints.

A drawback of the financial dependence measure is that it only varies at the industry level and therefore cannot account for variation in financial constraints across firms within an industry. Due to these limitations, a further test on the financial constraint hypothesis is conducted using the Quiscore, obtained from FAME. The Quiscore is a proprietary index of firms' creditworthiness where a higher score indicates greater creditworthiness. Firms with a score of above 80 are identified as being 'secure' and at the lowest risk of defaulting on loans. ${ }^{7}$ The variables used in the computation of Quiscore are similar to the ones used for Altman's Z score but excludes market value data. This is advantageous in our context since the index can be computed for both public and private firms. For the purpose of our analysis we assume that these firms are less likely to face financial constraints because creditors are more likely to provide finance to these firms. In contrast, we define firms with a Quiscore below 80 as likely to be affected by financial constraints. On this basis we construct a dummy variable equal to one for all firms with a Quiscore of less than or equal to 80 (in section 5.4 we discuss results using an alternative threshold), zero otherwise. This dummy variable is

\footnotetext{
${ }^{7}$ For instance, Guariglia and Mateut (2010) find that firms with a relatively low Quiscore are more likely to be financially constrained as evidenced by higher sensitivity of investment to the availability of finance. In general, credit ratings are often used to classify firms that are likely to face financing constraints (see, for instance Carreira and Silva, 2010 for an overview and Czarnitzki and Hottenrott, 2011 for an application to R\&D).
} 
defined on the basis of the Quiscore in the year before the buyout ( $t-1)$, so that our analysis can capture any effect of PE firms in relaxing financial constraints. Unfortunately, using the Quiscore reduces the number of LBO deals in the sample due to incomplete coverage.

The results using the dummy variable constructed from the Quiscore are reported in Table 7. Panel $\mathrm{A}$ and $\mathrm{B}$ indicate that LBO transactions, other than private-to-privates, have no significant impact on patenting in portfolio firms whether or not they have a low Quiscore. In contrast, Panel B shows that private-to-private LBO transactions have a positive effect on the quality-adjusted patent stock of firms that are more likely to be financially constrained. This is again consistent with PE firms increasing innovation output through the alleviation of financial constraints. A drawback of the Quiscore measure is that it may be correlated with other firm characteristics including the riskiness of firms. We partly address this issue in sections 5.4 and 5.5.

While it is not possible to directly observe the role of PE firms in relaxing financial constraints, this section has presented three sets of analysis in order to build a consistent picture of PE firms alleviating financial constraints in LBO targets. First, we find that the principal effect of PE firms on innovation outcomes stems from private-to-private LBO transactions. Second, we find that the effects of private-to-private LBO transactions are most pronounced for portfolio firms operating in industries with a high dependence on external finance. Finally, we show that private-to-private LBO transactions of firms with lower creditworthiness, which we argue are more likely to be financially constrained, have the largest effect on quality-adjusted patenting. The results present a general picture of privateto-private LBO transactions having a positive causal effect on patent stock and citationweighted patent stock. This is consistent with PE firms relaxing financial constraints in 
private-to-private deals, leading not only to increased patenting but also to an increase in quality-adjusted innovation output.

\subsection{The impact of PE firm and LBO governance characteristics}

While our results support the argument that PE firms relax financial constraints in private-toprivate LBO transactions, we cannot rule out that other factors associated with PE firms and the post-LBO governance structure impact innovation output. We therefore augment the model reported in Table 6 with a range of variables previously found to be correlated with portfolio firms' innovation and growth (e.g. Ughetto, 2010; Melueman et al., 2009). PE firms potentially gain organizational experience from their involvement in LBO deals and this experience can be shared with portfolio firms, we therefore include variables capturing experience as equity and debt providers. With some PE firms specializing in specific sectors of the economy, we also include debt and equity experience variables at the sector level to the analysis. Leverage has a role to play in bonding managers to pay out future cash flows in the form of interest payments, so leverage is added to the analysis. PE firms often use equity ratchets (performance-contingent contracts) to motivate the management to achieve performance targets. We are able to identify which portfolio firms have equity ratchets and include this variable. Further, we distinguish whether the LBO was a management buy-out (MBO), which involves incumbent management becoming significant equity holders, or a management buy-in (MBI), which involves external management becoming significant equity holders (Gilligan and Wright, 2014). Finally, we include two industry characteristics, the level of competition and a binary variable for manufacturing industries.

To avoid producing an overwhelming volume of results, we report whether the variables mentioned above have an effect on innovation outcomes for the period $t+3$ only in Table 8 . 
We first examine each variable separately to establish if there is a statistical relationship. The final column shows results from the specification including all variables. While there are some significant interaction terms for the effect on patent stocks (see Panel A), none of the additional variables have an impact on citation-weighted patent stocks (see Panel B). Most importantly, none of these additional variables affects our main results. It is noticeable that private-to-private LBO transactions in financially dependent industries continue to have the largest impact on patent stock and citation-weighted patenting after the inclusion of additional variables that explore alternative mechanisms through which LBOs impact on innovation. The additional analysis allows us to rule out several alternative explanations to PE firms relaxing financial constraints. Notably, we also find that the effect of post-LBO leverage and the interaction of leverage with PE firms are not significant, suggesting that the post-LBO leverage does not introduce a significant financial constraint.

\subsection{Robustness checks}

We conduct several robustness checks with respect to our estimation method and variable definitions. The object is to ensure our results are robust to sampling methods and the measurement of key variables. All these robustness checks are documented and discussed in more detail in a supplementary appendix which is available upon request. ${ }^{8}$ With respect to the matching method, our results are robust towards using a propensity score reweighting estimator instead of nearest neighbor matching, defining the treatment to be private-to-private LBO transactions, matching with replacement and using a broader classification of industries (to account for the fact that there is only a small number of LBO transaction is some 2-digit industries). Our results on financial dependence hold if we calculate a measure based on UK rather than US data. The results on firms with a low Quiscore are robust towards an

\footnotetext{
${ }^{8}$ We would like to thank two anonymous referees for suggesting some of these robustness checks.
} 
alternative threshold (70 instead of 80) and controlling for measures of uncertainty which might be correlated with Quiscore. We also verify that our results on citation weighted patents hold if we exclude citations indicating a high blocking potential and citations made by applicant citations.

\section{Conclusions}

This paper conducts an empirical analysis of a particularly contentious aspect of the entrepreneurial finance market. Specifically, we contribute to the debate concerning the role of PE firms in sacrificing longer-term investment opportunities in the pursuit of short-term profit. Critics argue that the necessity for PE firms to generate short-term returns for their fund investors motivates them to promote cost-cutting in order to generate short-term profit in portfolio firms. Entrepreneurial investment opportunities with a long-term pay-off are therefore passed over. We would therefore expect a reduction in innovation activity if shortterm cost-cutting is prioritized. In contrast, proponents argue that PE firms are able to alleviate capital market imperfections for entrepreneurial firms that are financially constrained. PE firms are a source of entrepreneurial finance and facilitate portfolio firms' access to external sources of finance. This allows portfolio firms to invest in innovation activity, which would not have been possible pre-LBO.

The results show that PE-backed LBOs have a positive causal effect on both patenting and quality-adjusted patents measured by forward citations. We show that LBOs cause an increase in novel patent activity rather than an increase in strategic patenting. Further analysis shows that the impact is predominantly driven by private-to-private LBO transactions, particularly in financially dependent industries and among firms that are more likely to be 
financially constrained before the LBO. The findings are consistent with PE firms relaxing financial constraints in portfolio firms, facilitating their investment in innovation activity.

We have controlled for a variety of other factors that might also impact on innovation. However, we would note that there are limitations of our empirical analyses. Our measure of innovation is limited to patent data which has well known limitations as we discuss in section 4.2. While our results indicate that strategic patenting is unlikely to be the main driver of our results, it has to be left for future research to analyze how PE affects broader measures of innovation such as new products and new processes in general. Although we provide a variety of results which are consistent with PE firms alleviating financing constraints, we cannot completely rule out alternative channels by which PE affects innovation. As such, our study opens the way for future research to attempt to measure financial constraints in portfolio firms before and after LBOs more directly.

\section{Acknowledgements}

We would like to thank participants at the "Economics of Entrepreneurship" Conference at the National Academy of Sciences in Washington DC, seminar participants at Mannheim and EM Lyon as well as two anonymous referees and the guest editors for helpful comments and suggestions. All remaining errors are our own.

\section{References}

Aghion, P., Van Reenen, J., Zingales, L., 2013. Innovation and Institutional Ownership. American Economic Review 103, 277-304.

Alperovych, Y., Amess, K., Wright, M. 2013. Private equity firm experience and buyout vendor source: What is their impact on efficiency? European Journal of Operational Research 228, 601-611.

Amore, M. D., Schneider, C., Zaldokas, A., 2013, Credit supply and corporate innovation. Journal of Financial Economics 109, 835-855.

Bebchuk, L. A., Fried, J. M., 2003. Executive compensation as an agency problem. Journal of Economic Perspectives 17, 71-92.

Bena, J., Li, K., 2014. Corporate Innovations and Mergers and Acquisitions. Journal of Finance 69, 1923-1960.

Behr, P., Norden, L., Noth F., 2013. Financial constraints of private firms and bank lending behaviour. Journal of Banking and Finance 37, 3472-3485. 
Berger, A. N., Udell, G. F., 1998. The economics of small business finance: the roles of private equity and debt markets in the financial growth cycle. Journal of Banking and Finance 22, 613-673.

Bertoni, F., Ferrer, M. A., Mart1, J., 2013. The different roles played by venture capital and private equity investors on the investment activity of their portfolio firms. Small Business Economics 40, 607-633.

Blind, K., Cremers, K., and Mueller, E. (2009), "The influence of strategic patenting on companies' patent portfolios", Research Policy 38, 2, 428-436.

Bloom, N., Draca, M., Van Reenen, J., 2011. Trade induced technical change? The impact of Chinese imports on innovation, IT and productivity, NBER working paper No. w16717.

Blundell, R., Costa Dias, M., 2000. Evaluation methods for non-experimental data. Fiscal Studies 21, 427-68.

Boucly, Q., Sraer, D., Thesmar, D., 2011. Growth LBOs. Journal of Financial Economics $102,432-453$.

Brown, J. R., Fazzari, S. M., Petersen, B. C., 2009. Financing innovation and growth: Cash flow, external equity, and the 1990s R\&D boom. Journal of Finance 64, 151-185.

Brown, J. R., Martinsson, G., Petersen, B. C., 2012. Do financing constraints matter for R\&D? European Economic Review 56, 1512-1529.

Budd, J. W., Konings, J., Slaughter, M. J., 2005. Wages and international rent sharing in multinational firms. Review of Economics and Statistics 87, 73-84.

Caliendo, M., Kopeinig, S., 2008). Some practical guidance for the implementation of propensity score matching. Journal of Economic Surveys 22, 31-72.

Carreira, C., Silva, F., 2010. No deep pockets: Some stylized empirical results on firms' financial constraints. Journal of Economic Surveys 24, 731-753.

Carpenter, R. E., Petersen, B. C., 2002. Is the growth of small firms constrained by internal finance? Review of Economics and Statistics 84, 298-309.

Caves, R. E., 1980. Corporate strategy and structure. Journal of Economic Literature 18, 6492.

Cressy, R., Malipiero, A., Munari, F., 2007. Playing to their strengths? Evidence that specialization in the private equity industry confers competitive advantage. Journal of Corporate Finance 13, 647-669.

Cumming, D., Siegel, D. S., Wright. M., 2007. Evaluating the financial and real effects of management buyouts and private equity investments. Journal of Corporate Finance $13,439-460$.

Czarnitzki, D., Hottenrott, H., 2011. Financial constraints: Routine versus cutting edge R\&D investment. Journal of Economics \& Management Strategy 20, 121-157.

Czarnitzki, D. and Toole, A., 2011. Patent protection, market uncertainty, and R\&D investment. Review of Economics and Statistics 93, 1, 147-159.

Demiroglu, C., James, C. M., 2010. The role of private equity group reputation in LBO financing. Journal of Financial Economics 96, 306-330.

Erel, I., Jang, Y. and Weisbach, M. S. 2015. Do acquisitions relieve target firms' financial constraints? Journal of Finance LXX, 1, .289-328.

Gilligan, J., Wright, M., 2014. Private Equity Demystified. ICAEW, London.

Griliches, Z., 1998. Patent statistics as economic indicators: A survey, in Z. Griliches (ed.), R\&D and Productivity: The Econometric Evidence, 287-343, University of Chicago Press, Chicago.

Grimpe, C. and Hussinger, K. (2008), "Pre-empting technology competition through firm acquisition", Economics Letters 100, 2, 189-191. 
Guadalope, M., Kuzmina, O., Thomas, C., 2012. Innovation and foreign ownership. American Economic Review 102, 3594-3627.

Guariglia, A., Mateut, S., 2010. Inventory investment, global engagement, and financial constraints in the UK: evidence from micro data. Journal of Macroeconomics 32, 239250.

Engel, D., Stiebale, J., 2014. Private equity, investment and financial constraints: firm-level evidence for France and the United Kingdom. Small Business Economics 43, 197212.

Hagedoorn, J., Cloodt, M., 2003. Measuring innovative performance: Is there an advantage in using multiple indicators? Research Policy 32, 1365-1379.

Hall, B. H., Ziedonis, R. H., 2001. The patent paradox revisited: An empirical study of patenting in the U.S. semiconductor industry, 1979-1995. RAND Journal of Economics 32, 101-128.

Helpman, E., Melitz, M. J., Yeaple, S. R., 2004. Export versus FDI with heterogeneous firms. American Economic Review 94, 300-316.

Hill, C. W. L., 1988. Internal capital market controls and financial performance in multidivisional firms. Journal of Industrial Economics 37, 67-83.

Holmstrom, B., Milgrom, P. R., 1991. Multitask principal agent analyses: Incentive contracts, asset ownership and job design. Journal of Law, Economics and Organization 7, 2452.

Hsu, P. H., Tian, X., Xu, Y., 2014, Financial development and innovation: Cross-country evidence. Journal of Financial Economics 112, 116-135.

Hubbard, R. G., 1998. Capital-market imperfections and investment. Journal of Economic Literature 36, 193-225.

Imbens, G., 2004. Nonparametric Estimation of Average Treatment Effects Under Exogeneity: A Review. Review of Economics and Statistics 86, 4-29.

Jelic, R., Wright, M. 2011. Exits, performance, and late stage private equity: The case of UK management buy-outs. European Financial Management 17, 560-593

Jensen, M. C., 1986. Agency costs of free cash flow, corporate finance and takeovers. American Economic Review Papers and Proceedings 76, 323-329.

Kaplan, S., Schoar, A., 2005. Private Equity Performance: Returns, Persistence, and Capital Flows. The Journal of Finance 60, 1791-1823.

Kaplan, S., Stromberg, P., 2009. Leveraged buyouts and private equity. Journal of Economic Perspectives 23, 121-46.

Konings, J. and Vandenbussche, H., 2005. Antidumping protection and markups of domestic firms. Journal of International Economics 65, 151-165.

Kroszner, R. S., Laeven, L., Klingebiel, D., 2007. Banking crises, financial dependence, and growth. Journal of Financial Economics 84, 187-228.

Laeven, L., Levine, R., Michalopoulos, S., 2013, Financial innovation and endogenous Growth. HOOVER IP ${ }^{2}$ Working Paper Series No. 14002. Available at SSRN: http://ssrn.com/abstract $=2382748$

Lerner, J., Sorensen, M., Stromberg, P., 2011. Private equity and long-run investment: the case of innovation. The Journal of Finance 66, 445-477.

Lichtenberg, F. R., Siegel, D., 1990. The effects of leveraged buyoutson on productivity and related aspects of firm behaviour. Journal of Financial Economics 27, 165-194.

Link, A. N., Ruhm, C. J., Siegel, D. S., 2014. Private equity and the innovation strategies of entrepreneurial firms: empirical evidence from the small business innovation research program. Managerial and Decision Economics 35, 103-113.

Long, W. F., Ravenscraft, D. J., 1993. LBOs, debt and R\&D intensity. Strategic Management Journal 14, 119-135. 
Meuleman, M., Amess, K., Wright, M., Scholes, L., 2009. Agency, strategic entrepreneurship and the performance of private equity backed buyouts. Entrepreneurship Theory and Practice 33, 213-239.

Miller, D. 1983. The correlates of entrepreneurship in three types of firms. Management Science 29, 770-791.

Morris, M., Kuratko, D., Covin, J., 2008. Corporate entrepreneurship and innovation. Mason, O. H.: Thomson/South-Western Publishers.

Nikoskelainen, E., Wright, M., 2007. The impact of corporate governance mechanisms on value increase in leveraged buyouts. Journal of Corporate Finance 13, 511-537.

Parisi, M. L., Schiantarelli, F., Sembenelli, A., 2006. Productivity, innovation and R\&D: micro evidence for Italy. European Economic Review 50, 2037-2061.

Rajan, R. G., Zingales, L., 1998. Financial Dependence and Growth. American Economic Review 88, 559-586.

Rappaport, A., 1990. The staying power of the public corporation. Harvard Business Review 68, 96-104.

Rosenbaum, P. R., Rubin, D. B., 1983. The central role of the propensity score in observational studies for causal effects. Biometrika 70, 41-55.

Seru, A., 2014. Firm boundaries matter: Evidence from conglomerates and R\&D activity. Journal of Financial Economics 111, 381-405.

Stein, J. C., 1988. Takeover threats and managerial myopia. Journal of Political Economy 96, 61-80.

Stiglitz, J., Weiss, A., 1981. Credit rationing in markets with imperfect information. American Economic Review 71, 393-410.

Thompson, S., Wright, M., 1995. Corporate governance: the role of restructuring transactions. Economic Journal 105, 690-703.

Thompson, S., Wright, M., Robbie, K., 1992. Management equity ownership, debt and performance: some evidence from UK management buyouts. Scottish Journal of Political Economy 39, 413-430.

Ughetto, E., 2010. Assessing the contribution to innovation of private equity investors: A study on European buyouts. Research Policy 39, 126-140.

Valkama, P., Maula, M., Nikoskelainen, E., Wright, M., 2013. Drivers of holding period firm-level returns in private equity- backed buyouts. Journal of Banking and Finance 37, 2378-2391.

Wang, Y., 2012. Secondary buyouts: Why buy and at what price? Journal of Corporate Finance 18, 1306-1325.

Williamson, O. E., 1975. Markets and Hierarchies: Analysis and Antitrust Implications. Free Press, New York.

Williamson, O. E., 1985. The Economic Institutions of Capitalism: Firms, Markets and Relational Contracting. Free Press, New York.

Wright, M., Hoskisson, R. E., Busenitz, L. W., Dial, J., 2000. Entrepreneurial growth through privatization: The upside of management buyouts. Academy of Management Review 25, 591-601.

Wright, M., Hoskisson, R., Busenitz, L., Dial, J., 2001. Finance and management buy-outs: agency versus entrepreneurship perspectives. Venture Capital 3, 239-261.

Wright, M., Robbie, K., 1998. Venture capital and private equity: a review and synthesis. Journal of Business Finance and Accounting 25, 521-570.

Zahra, S. A., 1995. Corporate entrepreneurship and financial performance: the case of management leveraged buyouts. Journal of Business Venturing 10, 225-247.

Ziedonis, R. H., 2004. Don't fence me in: Fragmented markets for technology and the patent acquisition strategies of firms. Management Science 50, 804-820. 
Table 1

Summary statistics and variable definitions

\begin{tabular}{|c|c|c|c|}
\hline Variable & Description & Mean & SD \\
\hline \multicolumn{4}{|c|}{ Firm and industry-level variables } \\
\hline $\mathrm{PE}$ & $=1$ if buyout in year $\mathrm{t}, 0$ else & 0.002 & \\
\hline Post_PE & $=1$ for all years after a buyout, 0 else & 0.010 & \\
\hline Patent count & Number of patent applications in current year & 0.048 & 1.817 \\
\hline $\begin{array}{l}\text { Quality-adjusted } \\
\text { patent count }\end{array}$ & $\begin{array}{l}\text { Number of patent applications in current year, } \\
\text { weighted by the number of citations }\end{array}$ & 0.983 & 128.1 \\
\hline Patent stock & Cumulated number of patents till current year & 0.406 & 11.078 \\
\hline $\begin{array}{l}\text { Quality-adjusted } \\
\text { patent stock }\end{array}$ & $\begin{array}{l}\text { Cumulated number of patents till year } t \text {, weighted } \\
\text { by citations }\end{array}$ & 20.614 & $1,405.1$ \\
\hline Strategic patents & Cumulated patents weighted by "XY" citations & 2.394 & 197.2 \\
\hline $\begin{array}{l}\text { Applicant-cited } \\
\text { patents }\end{array}$ & $\begin{array}{l}\text { Cumulated patents weighted by citations made by } \\
\text { patent applicants }\end{array}$ & 0.779 & 87.7 \\
\hline $\begin{array}{l}\text { Quality-adjusted } \\
\text { patent stock } 2\end{array}$ & $\begin{array}{l}\text { Cumulated patents weighted by citations } \\
\text { excluding "XY" and applicants' citations }\end{array}$ & 17.443 & 1145.4 \\
\hline Sales & Sales & 27,511 & 204,00 \\
\hline Employees & Number of employees & 206.5 & 1483.1 \\
\hline Capital & Tangible fixed assets & 9,481 & 95,848 \\
\hline Fixed assets & Fixed assets & 15,858 & 31,900 \\
\hline Labprod & Labour productivity, Sales per employee & 360.25 & 4,042 \\
\hline Cap_Emp & Capital per employee & 313.95 & 8,299 \\
\hline Age & Firm age in years & 22.014 & 21.215 \\
\hline Sales growth & Logarithmic yearly sales growth rate & 0.09 & 0.509 \\
\hline d_export & $=1$ if overseas sales $>0,0$ else & 0.325 & 0.469 \\
\hline Av_wage & Average wage per employee & 34.20 & 101.11 \\
\hline Profit_sales & Profits/Sales * 100 & 0.626 & 58.26 \\
\hline Leverage & Loans + overdrafts + liabilities / equity $* 100$ & 304.16 & 870.06 \\
\hline Quiscore & Inverse indicator of likelihood of default & 74.730 & 22.539 \\
\hline Findep & Industry-level financial dependence (US data) & 0.066 & 0.298 \\
\hline Findep(UK) & Industry-level financial dependence (UK data) & 0.217 & 0.377 \\
\hline Competition & Average of 1-Lerner Index (industry level) & 0.943 & 0.027 \\
\hline \multicolumn{4}{|c|}{ Variables at the PE firm / buyout level } \\
\hline Experience equity & \# of previous deals involving equity & 11.216 & 30.746 \\
\hline Experience debt & \# of previous deals involving debt & 29.283 & 27.930 \\
\hline Exp equity sector & \# of prev. deals involving equity in industry & 10.378 & 15.938 \\
\hline Exp debt sector & \# of prev. deals involving debt in industry & 15.865 & 23.617 \\
\hline PE $\times$ Pub2Priv & $=1$ if public to private buyout & 0.091 & \\
\hline PE $\times$ Priv2Priv & $=1$ if private to private buyout & 0.472 & \\
\hline $\mathrm{PE} \times$ Divisional & $=1$ if divisional buyout & 0.283 & \\
\hline PE $\times$ Secondary & $=1$ if secondary buyout & 0.155 & \\
\hline Equity_syndicate & $=1$ for equity provider syndication & 0.025 & \\
\hline Debt_syndicate & $=1$ for debt provider syndication & 0.140 & \\
\hline Ratchet & $=1$ if PE firm uses an equity ratchet & 0.118 & \\
\hline
\end{tabular}


Table 2

Propensity score estimation, Probit model (Dependent variable $=\mathrm{PE})$

\begin{tabular}{lc}
\hline Independent variable & Coefficient (standard error) \\
\hline ln_sales & $0.200^{* * *}$ \\
ln_Labprod & $(0.018)$ \\
& $-0.158^{* * *}$ \\
d_export & $(0.027)$ \\
& $-0.091^{*}$ \\
ln_av_wage & $(0.047)$ \\
& 0.057 \\
ln_cap & $(0.040)$ \\
& 0.013 \\
ln_age & $(0.012)$ \\
Profit_sales & $-0.060 * * *$ \\
& $(0.019)$ \\
Leverage & 0.003 \\
Patent stock & $(0.010)$ \\
Patent citation stock & -0.00004 \\
& $(0.00003)$ \\
Observations & 0.001 \\
Pseudo R squared & $(0.001)$ \\
Log likelihood & -0.00001 \\
LR test (chi squared) & $(0.00003)$ \\
\hline Notes: (1) Robust standard errors in parentheses; $(2) * p<0.1, * * p<0.05, * * * p<0.01$. \\
\end{tabular}


Table 3

Balancing property

\begin{tabular}{ccccc}
\hline Variable & Sample & Treated & Control & $\mathrm{t}$-test, $\mathrm{p}>|\mathrm{t}|$ \\
\hline Propensity score & Unmatched & 0.0104 & 0.0024 & 0.000 \\
ln_sales & Matched & 0.0104 & 0.0104 & 0.998 \\
& Unmatched & 9.9017 & 8.8335 & 0.000 \\
ln_Labprod & Matched & 9.9017 & 9.8813 & 0.851 \\
& Unmatched & 4.6661 & 4.8842 & 0.000 \\
d_export & Matched & 4.6661 & 4.657 & 0.887 \\
& Unmatched & 0.3123 & 0.3249 & 0.616 \\
ln_av_wage & Matched & 0.3123 & 0.3381 & 0.468 \\
& Unmatched & 3.1276 & 3.2345 & 0.004 \\
ln_age & Matched & 3.1276 & 3.1846 & 0.196 \\
& Unmatched & 2.7396 & 2.7341 & 0.915 \\
ln_capital & Matched & 2.7396 & 2.7044 & 0.628 \\
& Unmatched & 7.8350 & 6.5577 & 0.000 \\
Patent stock & Matched & 7.8350 & 7.7925 & 0.796 \\
& Unmatched & 1.0098 & 0.3787 & 0.350 \\
Patent citation stock & Matched & 1.0098 & 0.5798 & 0.349 \\
& Unmatched & 25.833 & 20.599 & 0.927 \\
Profit_sales & Matched & 25.833 & 17.165 & 0.712 \\
& Unmatched & -.00893 & -.64032 & 0.829 \\
Leverage & Matched & -.00893 & -.03416 & 0.726 \\
& Unmatched & 256.65 & 303.20 & 0.280 \\
& Matched & 256.65 & 245.59 & 0.820 \\
\hline
\end{tabular}

Table 4

ATT from propensity score matching

\begin{tabular}{|c|c|c|c|}
\hline \multicolumn{4}{|l|}{ Panel A: Patent stock } \\
\hline & $t+1$ & $t+2$ & $t+3$ \\
\hline \multirow[t]{2}{*}{$\mathrm{PE}$} & $0.166^{*}$ & $0.278 * *$ & $0.383 * *$ \\
\hline & $(0.075)$ & $(0.121)$ & $(0.156)$ \\
\hline Number of observations & 814 & 814 & 814 \\
\hline \multicolumn{4}{|c|}{ Panel B: Citation-weighted patent stock } \\
\hline & $t+1$ & $t+2$ & $t+3$ \\
\hline \multirow[t]{2}{*}{$\mathrm{PE}$} & $0.747 * *$ & $1.127 * *$ & $1.292 * *$ \\
\hline & $(0.338)$ & $(0.518)$ & $(0.581)$ \\
\hline Number of observations & 814 & 814 & 814 \\
\hline
\end{tabular}

Notes: (1) The dependent variable is the change in the cumulated stock of patents in Panel A; (2) in Panel B, patents are weighted by forward citations; (3) PE is a dummy variable taking value one after a private equity financed buyout, zero otherwise; (4) All regressions include time dummies; (5) robust standard errors in parentheses; $(6) * \mathrm{p}<0.1 * * \mathrm{p}<0.05 * * * \mathrm{p}<0.01$. 
Table 5

Heterogeneous effects by deal type

\begin{tabular}{|c|c|c|c|}
\hline \multicolumn{4}{|l|}{ Panel A: Patent stock } \\
\hline & $t+1$ & $t+2$ & $t+3$ \\
\hline \multirow[t]{2}{*}{ PE $\times$ Priv2Priv } & $0.401 * *$ & $0.691 * *$ & $0.940 * * *$ \\
\hline & $(0.162)$ & $(0.269)$ & $(0.350)$ \\
\hline \multirow[t]{2}{*}{ PE $\times$ Pub2Priv } & -0.064 & $-0.130 *$ & -0.162 \\
\hline & $(0.043)$ & $(0.077)$ & $(0.101)$ \\
\hline \multirow[t]{2}{*}{ PE $\times$ Secondary } & -0.006 & -0.043 & -0.046 \\
\hline & $(0.034)$ & $(0.055)$ & $(0.072)$ \\
\hline \multirow[t]{2}{*}{$\mathrm{PE} \times$ Divisional } & -0.047 & $-0.090 *$ & $-0.113^{*}$ \\
\hline & $(0.030)$ & $(0.049)$ & $(0.061)$ \\
\hline Number of observations & 814 & 814 & 814 \\
\hline \multicolumn{4}{|c|}{ Panel B: Citation-weighted patent stock } \\
\hline & $t+1$ & $t+2$ & $t+3$ \\
\hline \multirow[t]{2}{*}{ PE $\times$ Priv2Priv } & $1.662 * *$ & $2.520 * *$ & $2.902 * *$ \\
\hline & $(0.736)$ & $(1.138)$ & $(1.311)$ \\
\hline \multirow[t]{2}{*}{ PE $\times$ Pub2Priv } & -0.021 & 0.043 & 0.039 \\
\hline & $(0.117)$ & $(0.218)$ & $(0.254)$ \\
\hline \multirow[t]{2}{*}{$\mathrm{PE} \times$ Secondary } & -0.103 & -0.205 & -0.261 \\
\hline & $(0.175)$ & $(0.280)$ & $(0.364)$ \\
\hline \multirow[t]{2}{*}{$\mathrm{PE} \times$ Divisional } & -0.074 & -0.131 & -0.156 \\
\hline & $(0.094)$ & $(0.152)$ & $(0.193)$ \\
\hline Number of observations & 814 & 814 & 814 \\
\hline
\end{tabular}

Notes: (1) The dependent variable is the change in the cumulated stock of patents in Panel A; (2) in Panel B, patents are weighted by forward citations; (3) PE is a dummy variable taking value one after a private equity financed buyout, zero otherwise; (4) Priv2Priv is a binary variable for private-toprivate deals, Pub2Priv is a binary variable for public-to-private deals, Secondary is a binary variable for secondary buyouts, and Divisional is a binary variable for divisional buyouts; (5) all regressions include time dummies; (6) robust standard errors in parentheses; (7) * p<0.1** $\mathrm{p}<0.05 * * * \mathrm{p}<0.01$. 
Table 6

The effect of LBOs on financially dependent firms

\begin{tabular}{lccc}
\hline Panel A: Patent stock & & & \\
\hline & $t+1$ & $t+2$ & $t+3$ \\
\hline PE & -0.040 & $-0.082^{*}$ & $-0.100^{*}$ \\
PE $\times$ findep & $(0.025)$ & $(0.041)$ & $(0.051)$ \\
& -0.064 & -0.130 & -0.178 \\
PE $\times$ Priv2Priv & $(0.065)$ & $(0.127)$ & $(0.166)$ \\
& $0.297^{* *}$ & $0.598^{* *}$ & $0.808^{* *}$ \\
PE $\times$ Priv2Priv $\times$ findep & $(0.138)$ & $(0.260)$ & -0.341 \\
& $1.588^{* * *}$ & $1.981^{* * *}$ & $2.624 * * *$ \\
Findep & $(0.477)$ & $(0.682)$ & $(0.924)$ \\
& 0.047 & $0.112^{*}$ & $0.154 *$ \\
Number of observations & $(0.031)$ & $(0.066)$ & -0.085 \\
& 814 & 814 & 814 \\
\hline
\end{tabular}

Panel B: Citation-weighted patent stock

\begin{tabular}{lccc}
\hline & $t+1$ & $t+2$ & $t+3$ \\
\hline PE & -0.062 & -0.110 & -0.137 \\
PE $\times$ findep & $(0.071)$ & $(0.129)$ & $(0.166)$ \\
PE $\times$ Priv2Priv & -0.153 & -0.212 & -0.261 \\
& $(0.246)$ & $(0.459)$ & $(0.602)$ \\
PE $\times$ Priv2Priv $\times$ findep & $1.354^{*}$ & 1.717 & 2.086 \\
& $(0.799)$ & $(1.084)$ & $(1.302)$ \\
Findep & $4.044 * *$ & $9.807 * *$ & $10.282 * *$ \\
& $(1.767)$ & $(4.147)$ & $(4.352)$ \\
Number of observations & 0.087 & 0.195 & 0.231 \\
& $(0.078)$ & $(0.144)$ & $(0.179)$ \\
\hline
\end{tabular}

Notes: (1) the dependent variable is the change in the cumulated stock of patents in Panel A; in Panel B, patents are weighted by forward citations; (3) $P E$ is a dummy variable taking value one after a buyout, zero otherwise, Findep is a measure of financial dependence at the industry level, Priv2Priv is a dummy variable indicating private-to-private deals; (4) all regressions include time dummies; (5) standard errors in parentheses are clustered at the industry level; (6) * $\mathrm{p}<0.1 * * \mathrm{p}<0.05 * * * \mathrm{p}<0.01$. 
Table 7

The effect of LBOs on firms with a low Quiscore

\begin{tabular}{|c|c|c|c|}
\hline \multicolumn{4}{|l|}{ Panel A: Patent stock } \\
\hline & $t+1$ & $t+2$ & $t+3$ \\
\hline \multirow[t]{2}{*}{ PE } & 0.024 & 0.015 & 0.025 \\
\hline & $(0.179)$ & $(0.259)$ & $(0.335)$ \\
\hline \multirow[t]{2}{*}{$\mathrm{PE} \times \mathrm{D}($ quiscore $\leq 80)$} & -0.028 & -0.051 & -0.020 \\
\hline & $(0.313)$ & $(0.454)$ & $(0.586)$ \\
\hline \multirow[t]{2}{*}{ PE $\times$ Priv2Priv } & $0.488 * *$ & $0.901 * * *$ & $1.250 * * *$ \\
\hline & $(0.215)$ & $(0.312)$ & $(0.404)$ \\
\hline \multirow[t]{2}{*}{$\mathrm{PE} \times$ Priv2Priv* $\mathrm{D}($ quiscore $\leq 80)$} & 0.688 & 0.683 & 0.642 \\
\hline & $(0.438)$ & $(0.636)$ & $(0.822)$ \\
\hline \multirow[t]{2}{*}{$\mathrm{D}($ quiscore $\leq 80)$} & 0.002 & 0.019 & -0.022 \\
\hline & $(0.180)$ & $(0.261)$ & $(0.337)$ \\
\hline Number of observations & 377 & 377 & 377 \\
\hline
\end{tabular}

Panel B: Citation-weighted patent stock

\begin{tabular}{lccc}
\hline & $t+1$ & $t+2$ & $t+3$ \\
\hline $\mathrm{PE}$ & 0.073 & 0.228 & 0.236 \\
$\mathrm{PE} \times \mathrm{D}($ quiscore $\leq 80)$ & $(0.407)$ & $(1.018)$ & $(1.029)$ \\
& -0.031 & -0.300 & -0.260 \\
$\mathrm{PE} \times$ Priv2Priv & $(0.712)$ & $(1.783)$ & $(1.802)$ \\
& 0.707 & 0.851 & 0.978 \\
$\mathrm{PE} \times$ Priv2Priv $\times \mathrm{D}($ quiscore $\leq 80)$ & $(0.490)$ & $(1.227)$ & $(1.240)$ \\
& $1.713 *$ & $7.517 * * *$ & $7.365 * *$ \\
$\mathrm{D}($ quiscore $\leq 80)$ & $(0.998)$ & $(2.499)$ & $(2.525)$ \\
& -0.041 & 0.069 & 0.032 \\
Number of observations & $(0.410)$ & $(1.026)$ & $(1.037)$ \\
\hline N & 377 & 377 & 377 \\
\hline
\end{tabular}

Notes: (1) the dependent variable is the change in the cumulated stock of patents in Panel A; in Panel B, patents are weighted by forward citations; (3) $P E$ is a dummy variable taking value one after a buyout, zero otherwise; Quiscore is a measure of credit worthiness and $D$ (quiscore $<80$ ) takes on a value of one for levels of quiscore below 80 , zero otherwise, Priv2Priv is a dummy variable indicating private-to-private deals; (4) all regressions include time dummies; (5) standard errors in parentheses are clustered at the industry level; $(6) * \mathrm{p}<0.1 * * \mathrm{p}<0.05 * * * \mathrm{p}<0.01$. 
Table 8

Additional controls and interaction terms

\begin{tabular}{|c|c|c|c|c|c|c|c|c|c|}
\hline \multicolumn{10}{|l|}{ Panel A: Patent stock } \\
\hline & $t+3$ & $t+3$ & $t+3$ & $t+3$ & $t+3$ & $t+3$ & $t+3$ & $t+3$ & $t+3$ \\
\hline \multirow[t]{2}{*}{$\mathrm{PE}$} & $-0.076 * *$ & -0.069 & $-0.093 *$ & $-0.361 * *$ & -4.392 & -0.202 & -0.236 & -0.212 & 0.447 \\
\hline & $(0.036)$ & $(0.060)$ & $(0.048)$ & $(0.164)$ & $(2.759)$ & $(0.202)$ & $(0.194)$ & $(0.223)$ & (3.134) \\
\hline \multirow[t]{2}{*}{$\mathrm{PE} \times$ findep } & -0.165 & -0.186 & -0.170 & $-1.239^{*}$ & -0.210 & -0.178 & -0.236 & -0.165 & $-1.262^{*}$ \\
\hline & $(0.148)$ & $(0.170)$ & $(0.159)$ & $(0.660)$ & $(0.170)$ & $(0.175)$ & $(0.215)$ & $(0.154)$ & $(0.672)$ \\
\hline \multirow[t]{2}{*}{ PE $\times$ Priv2Priv } & $0.817 * *$ & $0.788 * *$ & $0.801 * *$ & $0.723 * *$ & $0.801 * *$ & $0.780 * *$ & $0.778 * *$ & $0.828 * *$ & $0.674 * *$ \\
\hline & $(0.350)$ & $(0.334)$ & $(0.336)$ & $(0.307)$ & $(0.339)$ & $(0.321)$ & $(0.316)$ & $(0.366)$ & $(0.287)$ \\
\hline \multirow[t]{2}{*}{ PE $\times$ Priv 2 Priv $\times$ findep } & $2.598 * * *$ & $2.627 * * *$ & $2.629 * * *$ & $3.029 * * *$ & $2.656^{* * *}$ & $2.644 * * *$ & $2.729 * * *$ & $2.629 * * *$ & $3.107 * * *$ \\
\hline & $(0.895)$ & $(0.925)$ & $(0.931)$ & $(1.086)$ & $(0.927)$ & $(0.955)$ & $(1.003)$ & $(0.917)$ & $(1.151)$ \\
\hline \multirow[t]{2}{*}{ findep } & $0.154^{*}$ & $0.153^{*}$ & $0.142 *$ & $0.106^{*}$ & $0.154^{*}$ & $0.153^{*}$ & $0.156^{*}$ & $0.153^{*}$ & 0.092 \\
\hline & $(0.086)$ & $(0.085)$ & $(0.081)$ & $(0.058)$ & $(0.086)$ & $(0.084)$ & $(0.090)$ & $(0.084)$ & $(0.063)$ \\
\hline \multirow[t]{2}{*}{$\mathrm{PE} \times$ ratchet } & -0.244 & & & & & & & & -0.148 \\
\hline & $(0.331)$ & & & & & & & & $(0.285)$ \\
\hline \multirow[t]{2}{*}{ PE $\times$ Equity_syndicate } & & $-0.217 * *$ & & & & & & & -0.026 \\
\hline & & $(0.100)$ & & & & & & & $(0.293)$ \\
\hline \multirow[t]{2}{*}{ PE $\times$ Debt_syndicate } & & -0.114 & & & & & & & -0.174 \\
\hline & & $(0.088)$ & & & & & & & $(0.156)$ \\
\hline \multirow[t]{2}{*}{ PE $\times$ leverage } & & & -0.000 & & & & & & -0.000 \\
\hline & & & $(0.000)$ & & & & & & $(0.000)$ \\
\hline \multirow[t]{2}{*}{ Leverage } & & & -0.000 & & & & & & -0.000 \\
\hline & & & $(0.000)$ & & & & & & $(0.000)$ \\
\hline \multirow[t]{2}{*}{$\mathrm{PE} \times$ manufacturing } & & & & $1.338 * *$ & & & & & $1.377 * *$ \\
\hline & & & & $(0.542)$ & & & & & $(0.583)$ \\
\hline \multirow[t]{2}{*}{ Manufacturing } & & & & 0.079 & & & & & 0.084 \\
\hline & & & & $(0.096)$ & & & & & $(0.094)$ \\
\hline \multirow[t]{2}{*}{$\mathrm{PE} \times$ competition } & & & & & 4.553 & & & & -1.075 \\
\hline & & & & & (2.936) & & & & (3.695) \\
\hline \multirow[t]{2}{*}{ Competition } & & & & & -0.461 & & & & -0.502 \\
\hline & & & & & $(0.991)$ & & & & $(0.990)$ \\
\hline \multirow[t]{2}{*}{ PE $\times$ Experience_equity } & & & & & & -0.003 & & & -0.006 \\
\hline & & & & & & $(0.005)$ & & & $(0.009)$ \\
\hline \multirow[t]{2}{*}{$\mathrm{PE} \times$ Experience_debt } & & & & & & 0.005 & & & 0.003 \\
\hline & & & & & & $(0.006)$ & & & $(0.004)$ \\
\hline \multirow[t]{2}{*}{$\mathrm{PE} \times$ Exper_equity_sector } & & & & & & & -0.001 & & 0.001 \\
\hline & & & & & & & $(0.002)$ & & $(0.003)$ \\
\hline \multirow[t]{2}{*}{ PE $\times$ Exper_debt_sector } & & & & & & & 0.010 & & 0.008 \\
\hline & & & & & & & $(0.011)$ & & $(0.010)$ \\
\hline \multirow[t]{2}{*}{$\mathrm{PE} \times \mathrm{MBI}$} & & & & & & & & 0.226 & 0.277 \\
\hline & & & & & & & & $(0.374)$ & $(0.410)$ \\
\hline Number of observations & 814 & 814 & 814 & 814 & 814 & 814 & 814 & 814 & 814 \\
\hline
\end{tabular}




\begin{tabular}{|c|c|c|c|c|c|c|c|c|c|}
\hline & $t+3$ & $t+3$ & $t+3$ & $t+3$ & $t+3$ & $t+3$ & $t+3$ & $t+3$ & $t+3$ \\
\hline \multirow[t]{2}{*}{$\mathrm{PE}$} & -0.157 & -0.051 & -0.074 & -0.694 & -3.023 & -0.798 & -0.614 & -0.272 & 8.081 \\
\hline & $(0.197)$ & $(0.176)$ & $(0.157)$ & $(0.604)$ & $(7.381)$ & $(0.931)$ & $(0.740)$ & $(0.697)$ & (13.479) \\
\hline \multirow[t]{2}{*}{$\mathrm{PE} \times$ findep } & -0.272 & -0.280 & -0.252 & -2.531 & -0.269 & -0.245 & -0.478 & -0.246 & -2.657 \\
\hline & $(0.561)$ & $(0.622)$ & $(0.582)$ & $(2.579)$ & $(0.587)$ & $(0.640)$ & $(0.839)$ & $(0.549)$ & $(2.662)$ \\
\hline \multirow[t]{2}{*}{ PE $\times$ Priv2Priv } & 2.079 & 2.030 & 2.054 & 1.904 & 2.087 & 1.884 & 1.948 & 2.110 & 1.615 \\
\hline & (1.326) & $(1.284)$ & $(1.285)$ & $(1.178)$ & $(1.309)$ & (1.144) & (1.177) & (1.380) & $(1.024)$ \\
\hline \multirow[t]{2}{*}{ PE $\times$ Priv2Priv $\times$ findep } & $10.304 * *$ & $10.285^{* *}$ & $10.296^{* *}$ & $11.145^{* *}$ & $10.277 * *$ & $10.418^{* *}$ & $10.694 * *$ & $10.287 * *$ & $11.450 * *$ \\
\hline & $(4.328)$ & $(4.346)$ & $(4.371)$ & $(4.835)$ & $(4.348)$ & $(4.563)$ & $(4.847)$ & $(4.361)$ & $(5.302)$ \\
\hline \multirow[t]{2}{*}{ findep } & 0.231 & 0.231 & 0.204 & 0.135 & 0.245 & 0.225 & 0.238 & 0.230 & 0.091 \\
\hline & $(0.181)$ & $(0.179)$ & $(0.156)$ & $(0.132)$ & $(0.184)$ & $(0.179)$ & $(0.183)$ & $(0.175)$ & $(0.128)$ \\
\hline \multirow[t]{2}{*}{$\mathrm{PE} \times$ ratchet } & 0.202 & & & & & & & & 0.368 \\
\hline & $(2.195)$ & & & & & & & & $(2.105)$ \\
\hline \multirow[t]{2}{*}{ PE $\times$ Equity_syndicate } & & -0.509 & & & & & & & 0.654 \\
\hline & & $(0.542)$ & & & & & & & $(0.980)$ \\
\hline \multirow[t]{2}{*}{ PE $\times$ Debt_syndicate } & & -0.322 & & & & & & & -0.557 \\
\hline & & $(0.274)$ & & & & & & & $(0.586)$ \\
\hline \multirow[t]{2}{*}{ PE $\times$ leverage } & & & -0.000 & & & & & & -0.000 \\
\hline & & & $(0.000)$ & & & & & & $(0.000)$ \\
\hline \multirow[t]{2}{*}{ Leverage } & & & -0.000 & & & & & & -0.000 \\
\hline & & & $(0.000)$ & & & & & & $(0.000)$ \\
\hline \multirow[t]{2}{*}{$\mathrm{PE} \times$ manufacturing } & & & & 2.861 & & & & & 3.162 \\
\hline & & & & $(2.371)$ & & & & & $(2.583)$ \\
\hline \multirow[t]{2}{*}{ Manufacturing } & & & & 0.159 & & & & & 0.197 \\
\hline & & & & $(0.312)$ & & & & & $(0.308)$ \\
\hline \multirow[t]{2}{*}{ PE $\times$ competition } & & & & & 3.064 & & & & -10.263 \\
\hline & & & & & $(7.869)$ & & & & $(16.015)$ \\
\hline \multirow[t]{2}{*}{ Competition } & & & & & -3.996 & & & & -4.083 \\
\hline & & & & & $(2.832)$ & & & & (3.006) \\
\hline \multirow[t]{2}{*}{ PE $\times$ Experience_equity } & & & & & & -0.029 & & & -0.047 \\
\hline & & & & & & $(0.023)$ & & & $(0.034)$ \\
\hline \multirow[t]{2}{*}{ PE $\times$ Experience_debt } & & & & & & 0.036 & & & 0.031 \\
\hline & & & & & & $(0.033)$ & & & $(0.027)$ \\
\hline \multirow[t]{2}{*}{$\mathrm{PE} \times$ Exper_equity_sector } & & & & & & & -0.006 & & 0.011 \\
\hline & & & & & & & $(0.007)$ & & $(0.009)$ \\
\hline \multirow[t]{2}{*}{ PE $\times$ Exper_debt_sector } & & & & & & & 0.039 & & 0.021 \\
\hline & & & & & & & $(0.044)$ & & $(0.033)$ \\
\hline \multirow[t]{2}{*}{$\mathrm{PE} \times \mathrm{MBI}$} & & & & & & & & 0.273 & 0.444 \\
\hline & & & & & & & & $(1.146)$ & $(1.292)$ \\
\hline Number of observations & 814 & 814 & 814 & 814 & 814 & 814 & 814 & 814 & 814 \\
\hline
\end{tabular}

Notes: (1) The dependent variable is the change in the patent stock (measured at period $t+3$ ) in Panel A; (2) in Panel B, patents are weighted by forward citations; (3) PE is a dummy variable taking value one after a buyout, Priv2Priv indicates private-to-private deals, Equity_syndicate (Debt_syndicate) is a dummy variable indicating two or more equity (debt) providers, ratchet is a dummy variable indicating whether an equity ratchet is used, Manufacturing indicates manufacturing industries, leverage is a debt equity ratio, experience_equity is the cumulative number of deals in which a PE firm has provided equity, experience_debt is the cumulative number of deals in which a PE firm has provided equity, findep measures financial dependence, and Competition is measured as 1 minus the average of the Lerner Index (price-cost margin) within industries; (4) all regressions include time dummies; (5) Robust standard errors in parentheses; (6) * $\mathrm{p}<0.1 * * \mathrm{p}<0.05 * * * \mathrm{p}<0.01$. 